\title{
New Yorkers' Street Smarts and Survival Smarts During the Pandemic: Preppers, Community Resilience and Local Citizenship
}

\author{
Anna Maria Bounds*
}

\begin{tabular}{|c|c|}
\hline ARTICLE INFO & ABSTI \\
\hline $\begin{array}{l}\text { Received: June 15, } \\
2020 .\end{array}$ & $\begin{array}{l}\text { This qualitative study examines the impact of the COVID-1 } \\
\text { pandemic on the philosophy and practices of New York }\end{array}$ \\
\hline $\begin{array}{l}\text { Received in revised } \\
\text { form: August } 01,2020 .\end{array}$ & $\begin{array}{l}\text { urban prepper subculture. My three research goals are to: } \\
\text { explore preppers' approaches to protecting their famili } \\
\text { against the pandemic, and how their commitment to sel }\end{array}$ \\
\hline $\begin{array}{l}\text { Accepted: October 01, } \\
2020 .\end{array}$ & $\begin{array}{l}\text { reliance may have changed; 2) describe the differe } \\
\text { experiences of surviving a pandemic in New York, a glob } \\
\text { capital that is sharply divided by class and race; and } 3 \text { ) analy: }\end{array}$ \\
\hline Published online: & $\begin{array}{l}\text { the possible benefits of community resilience rooted in a sens } \\
\text { of strong social bonds. For urban preppers, the government }\end{array}$ \\
\hline November 15,2020 & $\begin{array}{l}\text { failure to enact a clear response to the pandemic reaffirm } \\
\text { their core belief: the government was not coming to help ther } \\
\text { But while they had a strong foundation for successfull } \\
\text { sheltering in place, they did not anticipate the challenges } \\
\text { working from home, remote learning, and staying in or } \\
\text { location for such an extended time period. }\end{array}$ \\
\hline
\end{tabular}

Key words: COVID-19; New York City; urban cultures; class and race

To cite this article: Bounds, A. M., V. (2020). New Yorkers' Street Smarts and Survival Smarts During the Pandemic: Preppers, Community Resilience and Local Citizenship. Urbana, XXI. Retrieved from http://www.urbanauapp.org/ https://doi.org/10.47785/urbana.5.2020

\footnotetext{
* Corresponding author. Ph.D., Sociology Department, Queens College at the City University of New York
} 


\section{New Yorkers' Street Smarts and Survival Smarts During the Pandemic: Preppers, Community Resilience and Local Citizenship}

\section{Introduction}

By mid-March, 2020, New York was the first epicenter of the COVID-19 pandemic in the US. By the end of June, the virus had ravaged the city, with more than 215,000 confirmed cases, and over 23,000 deaths, representing $8 \%$ of confirmed cases in the U.S., $18 \%$ of deaths domestically, and $5 \%$ globally (Partnership for New York City, July 2020). With nearly 1.6 million unemployment applications filed, the city's unemployment rate reached $19.8 \%$ and is projected to average $10.9 \%$ in 2021 (Partnership for New York City, June 2020). As New York begins to reopen its economy, lost tax revenue in the state and the city will exceed $\$ 37$ billion in the next two fiscal years (New York State Department of Labor, 2020). The COVID-19 pandemic has also exposed New York's staggering inequalities. As a global capital with a diverse population and a complex economy, the city's sharp divisions of class and race have been mirrored in the pandemic's impact. Beyond age, race and income are the most significant factors in determining one's chances for surviving the pandemic (Schwirtz \& Cook, 2020). An analysis of COVID-19 deaths by ZIP code indicated that the highest death rates were in low-income neighborhoods with disproportionate numbers of Black and Latinx people (New York City Health Department, 2020). Shielded by its wealth, Manhattan had the lowest death rates. At the height of the pandemic, Blacks and Latinx residents were hospitalized and dying at twice the rate of White and Asian residents (Mays \& Newman, 2020). In the city's COVID-19 epicenter of Central Queens, the virus disproportionally affected workingclass immigrants in these communities (Correal \& Jacobs, 2020). Within these diverse immigrant communities, infection rates escalated among residents due to factors including preexisting chronic conditions, the lack of health insurance, language barriers, crowded housing, working high-exposure essential jobs, and high unemployment rates.

In terms of job loss within the city, only four sectors experienced minimal employment declines (less than 8\%): professional services (creative industries, finance and insurance, technology and legal); hospitals and healthcare; utilities and telecommunications, and grocery stores and other food-related retail. In contrast, the tourism sector (arts and entertainment, lodging and restaurants) and face-to-face sectors (manufacturing, retail, personal care, child care, and transportation) experienced job losses between 20\% to 50\% (Bowles \& Moran, 2020). At the time of writing, in June, many of the city's immigrant communities also have at least a $50 \%$ unemployment rate with no access to public subsidies, as undocumented workers are ineligible, and many others are fearful about applying (Amandolare et al., 2020). As noted by Viladrich (2020), "one of the main lessons of the COVID-19 crisis is that frontiers of race, ethnicity, class, and immigrant status are crucial axes of (in) equality that shape our differential exposure to the virus along with our likelihood of coming out triumphant over it."

While New York's death toll is staggering and the economic impact is colossal, to fully understand the pandemic's effect on New York, we must also examine the pandemic's effect on the everyday lives of New Yorkers, the lived experience (Lefebvre, 1991). The New York Urban 
prepping community gives us a unique lens into the lived experience of New Yorkers devoted to preparing for crisis, and can teach urban dwellers much about surviving a pandemic.

Prepping is an act of community resilience, "the capacity to anticipate risk, limit impact, and bounce back rapidly through survival, adaptability, evolution, and growth in the face of turbulent change" (Plodinec, 2009). For example, Huddleston's (2016) study of a Midwestern prepping group indicates that the micro-resilience of these groups enhances larger local systems and may improve a community's ability to withstand disaster. The philosophy of preparedness encompasses protecting one's families from disaster, homesteading and sustainability. Their belief in self-reliance, approaches to survival (sheltering in place or leaving the city), gathering resources (supplies and skills) and networking, demonstrate capacities of community resilience (Faulkner, 2018).

Urban prepping is also closely connected to urban citizenship - the city dweller's set of rights and responsibilities involving safety, political engagement, tolerance, recognition and freedom (Beauregard \& Bounds, 2000). Urban prepping emphasizes the rights to safety and the right to recognition. For people of color who recognize that their communities have been underserved in previous disasters, prepping represents agency and a demand for recognition to address inequalities in the distribution of resources and aid. In this regard, urban prepping makes an important break with misperceptions about preppers' motivations to prepare against disaster and the rationale behind their lack of trust in the government. As depicted in the mass media, a stereotypical prepper's drive to stockpile and prepare for disaster is spurred by conspiracy theories such as a fear of the sudden loss of first amendment rights. Conversely, after observing media coverage of communities of color and poor communities receiving little emergency support during disasters such as Hurricane Katrina and Hurricane Maria (Dyson, 2006; Deibert, 2019), an urban prepper may believe that one should prepare themselves for disaster without having to rely solely on government assistance. New York preppers are strengthening and prioritizing their social networks and claiming their right to recognition and resiliency. Therefore, New York preppers set about mastering the survival skills necessary to protect their families through learning how to "bug in" (shelter in place) or "bug out": determining how and when to leave the city for a safe destination.

This qualitative study examines the impact of the COVID-19 pandemic on the philosophy and practices of New York's urban prepper subculture. My three research goals are to: 1) explore how the prepping philosophy of self-reliance informed preppers' respective approaches to trying to protect their families against the pandemic, and how their commitment to self-reliance may have changed due to their experiences during the pandemic; 2) describe the different experiences of preparing for and surviving a pandemic in New York, a global capital that is sharply divided by class and race; and 3) analyze the possible impact of community resilience rooted in a sense of strong social bonds and accountability to one another. Exploring preppers' perspectives on and responses to COVID-19 offers insight into understanding the challenges that the pandemic has posed for all New York City dwellers. 
With strategies ranging from moderate to extreme, prepping refers to the practice adopted by individuals who prepare and plan to independently survive disaster (and sustain themselves) in a context of scarce food, dwindling supplies, and without government assistance (Mills, 2018; Perry, 2006; Reinhardt, 2017). With dwindling faith in the promise of government aid during disasters, these New Yorkers have turned to self-protection strategies to ensure their safety (Bounds, 2020). For this subculture, self-reliance and fostering social bonds are the keys to minimizing potential harm. Through conducting virtual in-depth interviews and online archival research, this study explores how the respective experiences of urban preppers during the COVID19 pandemic have influenced their expectations of government and their approaches to surviving disaster in New York City. While urban preppers have trained and practiced for disaster, the experience of actually living through and surviving the pandemic in New York has given these preppers the opportunity to test their philosophy of self-reliance and their survival skills.

The $21^{\mathrm{St}}$ century represents an era of intense public anxiety about government and economic instability, environmental catastrophes, pandemics and technological collapse (Beck, 2009). However, the rise of prepping in New York is not a phenomenon that can be attributed only to the national political context. Urban prepping is also about adapting to the changing nature of life as a city dweller. It is about local, everyday choices, planning for the future, and thinking about community. As a global city characterized by tremendous inequalities and increasing risk, New York provides a ripe context for prepping. From 2001-2020, New York has endured many severe crises (or threats of disaster) including five terrorist attacks, natural disasters (including two hurricanes, two tornadoes and an earthquake), technological failures (such as two blackouts), economic or government instability (the longest recession since World War II), the Swine Flu pandemic, fears of an Ebola Virus pandemic and, now in 2020, a deadly pandemic: COVID-19. This direct experience with disaster has motivated many New Yorkers to learn prepping skills. For these New Yorkers, city life now seems to require both street smarts and survival smarts.

\section{Background}

This qualitative study draws on Quarantelli's (2000, p. 682) consensus definition of disasters as "relatively sudden occasions when. . the routines of collective social units are seriously disrupted and when unplanned courses of action" must be taken, and that "disasters are social and that they are [to be] understood in human interactions" (Perry, 2006, p. 12). Throughout the many complex and sometimes competing definitions of disaster (Perry, 2018), the influence of culture and who has the power to define disaster and frame a crisis as disaster remains a constant (Webb, 2018). In recognition of the term's assigned meaning within this subculture, disaster is defined broadly to reflect the wide range of scenarios referred to within the prepping community as disasters, such as natural disasters, pandemics, terrorist attacks, nuclear and technological disasters, and the collapse of the global economy and national governments.

Mills (2018) argues that the American phenomenon of prepping is a response to anxieties around disaster risks that are driven by the consumption of disaster-based news reported in mainstream media, rather than any singular fixation on an impending apocalypse. Mills' finding 
is significant because it breaks free from the earlier limited contention that prepping is driven by the fear of a final and complete collapse of civilization (Foster, 2014) and is, rather, a reflection of disaster-based media and uncertainties about our current world. However, many real or predicted disasters that have been featured in American media have actually been experienced firsthand by New Yorkers with the COVID-19 pandemic being the most recent disaster. This direct experience with disaster now drives an urban prepping culture that is committed to practicality and selfsufficiency.

Scholarship on the prepper subculture is exploratory and emergent. Preppers face a bias, as American discourse has already categorized their activities as fringe or extreme behaviors (Huddleston, 2016). Preppers have been grouped with survivalists and other fringe groups such as militias and white supremacists even though their respective goals are quite different. Survivalist groups and other extremist groups have seized apocalyptical myths (religious or secular) and the ideologies of American individualism and exceptionalism to promote their distorted views of the world and its demise (Lamy, 1997, 1996). As Mitchell (2002) explains, in these groups, survivalism is not centered on "practical readiness for coming uncertainties" (p. 214) but on apocalyptic storytelling. Such storytelling "is primarily resistance to rationalization, to fixed meanings and predictable process, an encompassing game of make-believe" (p. 215). However, for New York preppers, their interest in learning survival skills is rooted in their understanding of city life. Direct experience with disaster in the city has been a primary motivation. The trials of urban life have also informed their perspective. Some urban preppers discovered early on that survival in the city demands self-reliance. Life experiences such as growing up poor in a dangerous neighborhood or growing up in an immigrant family with no social support network has taught some New York preppers the value of protecting one's self as well as the need to save resources (food or money) for a difficult time.

The drive to protect one's family from disaster has spurred a giant economy that expands well beyond the sales of traditional survivalist goods and prepping manuals. Prepping gear can now be found in stores ranging from Costco (tubs of Ready-to-Eat meals) to Pottery Barn (luxe go-bags stuffed with emergency supplies). The prepping economy now includes popular entertainment, outdoor recreation, sustainability and wellness. In popular entertainment, apocalyptic storylines and prepper characters allow viewers the thrill of participating in the destruction and rebirth of the world. The outdoor recreation market also appeals to preppers through its diverse array of camping gear (often repackaged as survival items), nature courses and adventure retreats. Preppers also often support sustainability by growing or purchasing organic and local foods. Through the wellness market, preppers become certified in first aid, learn natural remedies, and practice mindfulness and situational awareness techniques to increase their resilience in a disaster.

National Geographic's hit reality television series, Doomsday Preppers, introduced America to the prepper stereotype: a camouflage-wearing and gun-toting male fixated on protecting himself and his loved ones against a dangerous unknown. The series profiled (and sometimes mocked) preppers who stockpiled supplies, weapons and other items to prepare for the 
apocalypse. Through staged performances of masculine labor and rituals, this show cast prepping as a predominately white masculine activity (Kelly, 2016). The stereotype was reinforced by other reality television shows such as Apocalypse Preppers, Doomsday Castles and Meet the Preppers. In addition to television shows, popular American movies (such as Mad Max: Fury Road) were also cashing in on our fear of the apocalypse, offering "a glimpse of what the end might be likethought experiments that provoke us to think about the unthinkable, dress rehearsals for a show we hope will never open" (Biskind, 2018, p. 25). As these "on screen" preppers engage in intense labor and invent novel ways to escape disaster, their actions encourage viewers to tap into the collective belief in the power of the fierce white male hero, full of bravado and might, that has a starring role in the popular American imagination.

However, reality often conflicts with imagination. My research indicates that this media stereotype of the American prepper disappears in the context of New York. New York preppers are not exclusively white males who exhibit traits of hegemonic masculinity. Like their city, New York preppers reflect diversity. Preppers are African American. Preppers are Puerto Rican. Preppers are Mexican. Preppers are Asian. Many preppers are women. These are the people left out of the "white male prepper as hero" narrative. Breaking away from the image of preppers as isolated and paranoid people, New York preppers are often engaged community members. Many of these preppers are middle-class parents, like first responders or office administrators, who are concerned about protecting their children. However, the New York prepping world also includes America's extremely wealthy whites - multimillionaires and billionaires. For these white elites, prepping has little to do with independently surviving disaster in difficult conditions. Their disaster preparedness involves escaping to a private hideaway or retreating to a luxurious safe room. Given this study's focus on the impact of COVID-19 on New York, a detailed analysis of these wealthy preppers' strategies for removing themselves from the collective experience of disaster (by leaving the city) to relocate to other areas is beyond the scope of this article.

\section{Method}

My experience living through multiple crises as a New Yorker, which includes my sheltering in place experience during the COVID-19 pandemic for over 100 days, and enduring previous crises such as Hurricane Irene and Hurricane Sandy as well as three terrorist attacks, allows me a unique sociological lens for conducting this research. My goal in this research has been to provide a "thick" description (Geertz, 1973) of how urban preppers have utilized their prepping skills and knowledge to survive the pandemic and how they plan to revise or refine their approaches to improve their respective quality of life as the pandemic continues.

Data for this project was collected through conducting virtual and phone in-depth interviewing and online archival research. To develop an understanding of how New York preppers prepared for and have lived during the pandemic, I conducted 30 in-depth interviews with New York City preppers, including members of two urban prepping groups, the New York City Preppers Network (NYCPN) and Urban and Outdoor Survival (UOS) as well as independent preppers. Both the NYCPN (486 members) and the UOS (153 members) learn and practice 
preparedness strategies through lectures, workshops, and excursions. I attended online meetings of the NYCPN as an academic researcher. I also interviewed "independent preppers" (preppers not connected with any prepping group) across the five boroughs who maintained substantial provisions to prepare against disaster. To assess demand for prepping goods and services, I interviewed owners of popular prepping gear websites.

Interview questions were designed to address the following broad categories: approaches to surviving the pandemic (such as sheltering-in-place or leaving the city), prepping skills and equipment that were most useful, unexpected challenges during the pandemic, the use of community networks for exchanging information and providing assistance, perceptions of life during the pandemic, and preparations or adjustments for continuing to endure the pandemic. Writ large, these urban preppers' experiences offer insight into understanding the experience of New Yorkers living in the US's first COVID-19 epicenter and discovering possible community resilience strategies for city dwellers.

Archival research involved collecting three categories of documents: 1) reports on the pandemic in New York, including COVID-19's effect on poor and immigrant communities; 2) media coverage of New York preppers and prepping strategies; 3) New York preppers' social media posts about practicing prepping. Reports include policy documents and televised presentations by government officials and agencies (federal, state, local), reports published by nonprofits such as community advocacy and public health organizations, press coverage and historical records of past epidemics in New York. Media coverage of New York preppers and prepping strategies during the pandemic includes print, digital services, podcasts and television. New York prepper social media posts refers to public communication such as Instagram feeds, Twitter messages and Facebook posts.

\section{Findings and Discussion}

New York's Contemporary History of Disaster

As COVID-19 tore through the city in late March 2020, Governor Cuomo sought to boost the morale of New Yorkers by reminding them of their steeliness. In his daily television press conference (Cuomo, March 2020), he told New Yorkers:

"We're going to get through it because we are New York and because we've dealt with a lot of things, and because we are smart. You have to be smart to make it in New York. And we are resourceful, and we are showing how resourceful we are. And because we are united, and when you are united, there is nothing you can't do. And because we are New York tough. We are tough. You have to be tough. This place makes you tough, but it makes you tough in a good way."

While Cuomo's words were intended to steady the nerves of an anxious public, his statement emphasizes the fact that living in New York in the $21^{\text {st }}$ century is, in fact, tough. Since the start of this century, New York has endured significant disasters (or threats of disasters) that make up the main categories of concern for urban preppers: terrorist attacks, technological failures, natural disasters, government or economic collapse, and pandemics. These crises have fueled interest in urban prepping. 
Beginning with the September $11^{\text {th }}$ terrorist attack on the World Trade Center, New York has experienced five terrorist attacks in Manhattan: World Trade Center Attack (2001), Failed Car Bombing of Times Square (2010), Chelsea Bomb Explosion (2016), Truck Driven into People on West Side Bike Path (2017) and the Times Square-Port Authority Subway Bomb PartialDetonation (2017). Not all attacks were successful; however, all attacks were attempted in commercial or public spaces with the goal of causing tremendous loss of life and property damage.

Life in New York has also been disrupted by significant technological failures. The Northeastern Blackout (2003) left 50 million people without power in eight Northeastern states and parts of Canada (Barron, 2003). New Yorkers were without power for nearly two days, including thousands who were without mass transit. Different types of explosions have also resulted in the loss of life. In 2016, three East Village buildings exploded due to an illegal gas line tap, killing 2 and injuring 19 (McKinley, Jr. \& Santora, 2016). This technological failure was initially feared to be a terrorist attack by some New Yorkers. However, greed and the chance to generate more rental income were the culprits.

In addition, New York has experienced its fair share of natural disasters. In 2012, New York was struck by the worst storm in its history. Hurricane Sandy devastated the city by destroying neighborhoods, taking 43 lives, leaving 2 million residents without power and costing the city $\$ 19$ billion in damages (NYC Special Initiative for Rebuilding and Resiliency, 2013). Other hurricanes, tropical storms, tornadoes have also hit the city. Hurricane Irene (2011) struck the city with minor property damage and no storm-related fatalities in the city (Dolnick, 2011). Tornados also struck the Bronx, Brooklyn and Queens in 2010. The Brooklyn and Queens tornados caused extensive property damage and one fatality (Rivera \& Roston, 2010). The two boroughs were again struck by tornadoes the following year (Santora \& Magg, 2012) with Queens experiencing another tornado in 2018.

Financial crises and political crises have also affected New York. Lasting over eighteen months, the Great Recession was the longest of any recession since World War II (National Bureau of Economic Research, 2010). The economic downturn was driven by the financial crisis of 200709 and the related subprime mortgage crisis (Sorkin, 2009; Rajan, 2010). New York quickly felt the impact of significant job losses, a decline in tourism, and widespread mortgage loan defaults that affected entire neighborhoods in the outer boroughs (Halle \& Beveridge, 2013). The Occupy Wall Street (2011) political movement attempted to usurp the power of capital by protesting (and camping out) for roughly three months in New York's financial district. With their slogan: "We are the 99\%," Occupy Wall Street protesters rallied against the income and wealth inequality between America's richest 1\% and the rest of the nation. The protest called attention to the reality that "income inequality was grinding down the middle class, increasing the ranks of poor, and creating a permanent underclass of able, willing but jobless people" (New York Times Editorial, 2011). These harsh realities sparked anxiety among urban preppers about American's economic stability and social unrest.

Before the COVID-19 pandemic, New York, an international, was already at risk for the possible outbreak of pandemics and epidemics. In 2016, New York had 987 cases of Zika, with all 
of those linked to travel to a Zika-affected area (NYC Department of Health, 2019). A New York doctor who treated Ebola patients in Guinea, contracted the virus and received treatment and recovered during 2014 (Santora, 2014). In 2009, the city also endured an outbreak of the H1N1 influenza (Swine Flu) epidemic which infected roughly 550,000 people and resulted in 12 deaths (Hartocollis, 2009).

Experiencing this series of crises fueled an interest in urban prepping for some New Yorkers. For this group, learning preparedness and survival skills stems from direct experience rather than from imagining possible disaster scenarios. In the weeks before New York shuttered, Jason Charles, the lead organizer of the NYCPN, felt confident about his group's ability to withstand the pandemic based on their training and their ownership of personal protective equipment. As the pandemic has now spanned for six months, it has proven to be a critical test for these urban preppers to determine the strength their philosophy of preparedness and their survival skills.

To place COVID-19's impact in the context of New York's recent history of disaster, one must understand that the pandemic has had a greater effect on the city's public health and on its economy than the 9/11 terrorist attack, the Great Recession, or Hurricane Sandy (Parrott and Moe, 2020). COVID-19's catastrophic effect on the U.S. has been increased due to the federal government's failure to develop and execute a clear and coordinated plan for reducing the spread of virus across the country. Critical missteps were numerous. Examples include: the president's lack of response to early warnings about the virus; the failure to coordinate a national supply-chain for protective equipment and medication supplies and President Trump's unwillingness to fully utilize the Defense Production Act to generate needed supplies (Shear et al., 2020). The White House also provided an ever-changing and contradictory message about COVID-19: "The virus is not a threat; the virus is upon us. The economy must not be harmed; the economy must be shut down. There's no need to wear a mask; everyone should wear a mask - unless, like the president, you prefer not to" (McManus, 2020). Furthermore, eager to distance President Trump's reelection hopes from the pandemic's escalating death rate in the US and the collapsing economy, the White House "sought to shift responsibility for leading the fight against the pandemic to the states. . .referred to as the 'state authority handoff"'. (Shear et al., 2020). As the President explained to U.S. governors in issuing general guidelines for reopening states, "'You are going to call your own shots"" (Shear et al., 2020).

By late March 2020, New York was the epicenter of the pandemic. Facing a dire situation, and little federal support, Governor Cuomo began calling his own shots. The New York State government and the City Government of New York designed a coordinated plan to addresses critical healthcare issues such as the shortages of personal protective equipment for the hospital workers, bed shortages, and overwhelmed hospital staff. Measures included securing ventilators and other medical equipment, creating new hospital wards and recruiting nurses and doctors from across the United States. Governor Cuomo also held daily televised news conferences which provided transparency, critical real-time updates, encouraged adherence to COVID-19 policies, and were intended to boost the morale of New Yorkers. However, New York public health critics 
argue that Governor Cuomo was still too slow in implementing social distancing measures (New York waited to close schools, stores and restaurants after California and Washington.), and that if NY had started social distancing earlier, the outbreak would have been reduced by $50 \%$ to $80 \%$ (Goodman, 2020).

For urban preppers, the government's failure to enact a clear response to the pandemic reaffirmed their core belief: the government was not coming to save, aid or protect them. Instead, they would rely on themselves and their local networks for survival. One prepper argued that the federal government's inability to manage the COVID crisis resulted in "a game of 'Wack-A-Mole' where problems related to the virus and confusion keep popping up." These urban preppers expressed concerns similar to other Americans about the management of the pandemic such as the lack of presidential leadership, the shortage of protective equipment, and economic instability.

Marlon, a seasoned prepper and the leader of UOS, said, "Look, I said a long time ago that there was no calvary coming. The pandemic proved that I was right in my thinking. The president, exaggerating claims while people are dying. Governor Cuomo and Mayor DeBlasio squabbling and holding things up while people are dying. Stop having faith in these people. We have to take care of ourselves." To help his group of 153 members take care of themselves throughout the pandemic, Marlon has led meetings and workshops designed to improve their sheltering in place skills such as extending the serving size and shelf life of food.

Another long-time prepper's direct experience involving the shortage of personal protective equipment reinforced this lack of trust in the government's ability to meet the needs of citizens. In late March, this prepper posted an extra N95 mask for sale on an e-commerce site that facilitates consumer-to-consumer sales. As she recounted, "I ended up giving it away. I gave it to a doctor working in a Pediatrics Department. He said that the hospital had nothing for them so they were all searching and trying to buy their own stuff. How could I take his money? The man cares for children. I felt terrible. We all knew that there were going to be shortages, that it was going to be bad, but it's happened so quickly. A doctor searching around for his own supplies. I wanted to do something nice. I gave him a roll of toilet paper too. I mean, I wanted him to know that we are all in this together. Such a crazy thing. Toilet paper."

For Ron, another experienced urban prepper, government policies implemented to fairly allocate resources was an important indicator of security. He compared government interventions in aiding residents during the pandemic to government policies enacted during the aftermath of Hurricane Sandy. He recalled, "In Hurricane Sandy, there was a rationing of gas, there was a policy to deal with that shortage. Now, citizens have no confidence in government. They are fearing for the worst-case scenarios about everything? How has the government helped with the pandemic? Sure, they partially helped the economy with the stimulus package but that was after the virus had spread and after the first layoffs."

Now that COVID has made sheltering in place a necessity for many Americans, they have adopted prepping practices such as securing food and essential items to provide for their families. However, as Ron pointed out to me, trying to survive the pandemic does not make you a prepper. Rather, prepping requires an ongoing commitment. He explained, "Right now, people are 
definitely trying to prepare and look out for their families. What we do is different though. It's hard to prepare for all things. First, it takes time to figure out what you need and the skills you need to learn. Then, it takes time to learn new skills and to get up your supplies. We pay attention to things. We talk and exchange information ahead of regular people. We discussed this in November so we had time to prepare before people rushed out in March." In planning for the pandemic, New Yorkers were faced with choosing between two options: sheltering in place (staying at home) or leaving the city for a safe location (staying with a friend or family member or retreating to a second home or safe haven). For preppers, choosing between "bugging in" or "bugging out" is the first step of survival.

\section{Bugging In}

According to the Department of Homeland Security (DHS) (2019), "There may be situations, depending on your circumstances and the nature of the disaster, when it's simply best to stay where you are and avoid any uncertainty outside by 'sheltering in place." The New York State government officially mandated a state at home order on March 22 (Cuomo, April 2020). Unlike most New Yorkers, the urban preppers participating in this study had already developed plans for protecting their families against the spread of a deadly virus. Preppers plan extensively for sheltering in place. These preparations involve maintaining food and essential supplies, water storage, and sealing one's shelter against containments if needed. Given their commitment to selfreliance, urban preppers have a stronger foundation for resilience than most city dwellers. Prior to the pandemic, these urban preppers already had provisions for sheltering in place. Weeks before COVID-19 hit New York, urban preppers were inventorying their supplies and adding items as needed.

Throughout the pandemic, NYC preppers have also sought to bolster their safety by participating in information and resource networks. Based on a sense of trust established through a shared interest in preparedness, they engage in reciprocity and mutual assistance (Lalone, 2020). In contrast to the stereotype that casts preppers as suspicious loners, many NYC preppers have strong social networks and are often members of civic or parochial groups. For example, prior to COVID's spread to New York, urban preppers used information networks to exchange information about the potential threat of COVID and discussed their respective approaches to sheltering in place. During virtual meetings of both the NYCPN and the UOS, members exchanged information about the impact of the pandemic in their respective areas and networked for needed supplies (such as extra masks or disinfectant for new members). One prepper attributed his participation in social networks to his success in sheltering in place, "Working within groups and networks made me do better than an average person. This is about staying ahead of the curve. I always try to talk to people. You never know what you are going learn and how you could help each other. In the Fall, I spent a lot of concentrating on wilderness survival skills. After talking to and exchanging ideas with other preppers, I realized I need to switch gears. By January, I was finishing up my preps. I have connections to get most things. I also have an agreement with my neighbor to look out for each other." 
Beyond providing information and needed supplies, these networks also offered urban preppers encouragement and support as residents sheltering in place in epicenter of the virus. At an April NYCPN meeting about sheltering in place, Jason, the group's leader, encouraged members not to just look to prepping for stability but to also turn to whatever sense of spirituality members had to help them stay strong as the city's death rate escalated. Marlon, the leader of UOS, fielded calls from preppers and non-preppers needing to talk about a range of pressures caused by the pandemic such as the tragic passing of loved ones, job loss, and frustrations related to sheltering in place. This experience motivated Marlon to begin work on incorporating stress-reduction strategies into his classes on sheltering in place.

Many urban preppers improved the resilience of their communities by offering their neighbors helpful advice on preparing for the pandemic. LaChelle, a longtime prepper from Brooklyn observed, "We are vindicated -- not that we wanted to be. We want to help people. That's what this is about. You can't survive without being a community. That's why our country is having so much trouble; we all need to be working together. Everyone reached out to me. I texted supplies lists to my college friends. I worked with my family and friends. Everybody had questions about what to do." Resilience building activities among these preppers included: fielding questions by neighbors about preparations for the pandemic (in-person, on the phone, or via text), giving supplies (masks and gloves) to neighbors in need, organizing or participating in neighborhood networks to deliver medication and groceries to elderly or disabled residents. A Manhattan prepper organized a Facebook page for his apartment building so that neighbors could share news and help one another while sheltering in place. Tracy, a Queens prepper recounted, "My neighbor was sick with COVID in her home for 3 weeks. She is a senior and lives alone. Every day, I walked 10 blocks to bring her food. I prepped in January for 3 months of food, so I had plenty to share. There was suppose [sic] to be a food bank in NYC [sic] that would deliver food to her but they never came."

Although DHS (2020) suggests that Americans keep a three-day supply of food and water on hand, urban preppers interviewed had at least one month's of non-perishable food. At the start of the pandemic, policy experts and food distributors did not expect a food shortage in New York; however, there was concern about food-insecure populations and the increasing numbers of unemployed residents (Lederer, 2020). Before the pandemic,1.2 million New Yorkers were foodinsecure, including vulnerable groups such as senior citizens and school-age children who qualify for free or reduced-priced meals (The Mayor's Office for Food Policy, 2019). With the unemployment rate near 20\% in July 2020 (McGeehan, 2020), many more New Yorkers struggled to feed their families. As expressed by a New York Times reader in the comments section about an article on the city's high unemployment rate: "Life in New York I suspect will never be the same. Poor people will bear the most pain as they always do. Seeing people lining up for hours at food pantries is heartbreaking" (McGeehan, 2020).

As a preparation for sheltering in place, many NYC preppers maintain a "prepper closet," a dedicated space such as a closet or designated place in their homes that is reserved for storing critical supplies to help their families survive in severe circumstances. A "prepper closet" contains 
important provisions such as shelf-stable food, medical supplies (typically, a first aid kit and prescription medicines), cleaning supplies, large containers of water, flashlights and batteries, duct tape and tarps for sealing windows, and special items for family members (such as treats for children or sometimes alcohol for adults). In response to the early warning about the pandemic, NYC preppers also expanded their provisions to include extra masks (mainly N-95), face shields, disposable gloves, disinfectant and hand sanitizer (including ingredients to make hand sanitizer).

After concluding that power outages were not common in areas of China hit hard by the pandemic, some urban preppers decided to purchase deep freezers to stock up on meats and other frozen items. In response to minor shortages at grocery stores, urban preppers relied on their prepping closets to replace items that were out of stock (such as yeast for baking or a preferred brand of spaghetti sauce). As the death rate continued to escalate in the city from late March through mid-April, grocery stores trips began to be viewed as risky and resulted in grocery delivery services being overwhelmed and unable to meet the demand. Therefore, NYC preppers "shopped" their prepper closets. Given New York's rapid economic downtown, some prepper's closets (amply stocked with food) served as a vital buffer against hunger. For a Brooklyn couple, their prepper closet with one month's supply of food helped them to weather a job loss early in the pandemic. As the husband said, "Only one of us has a job that allows us to work virtually. The repair shop where I worked folded almost immediately. We were down to one income. Having a stockpile of food and everyday stuff took the edge off. We could stretch things out. It's helped us not to immediately deplete our savings. Otherwise, we would've gone through it like a buzzsaw."

Prepper closets were also used to store protective gear to prevent contracting COVID-19. Most urban preppers had an array of protective equipment such as masks (N-95), face shields, disposable gloves, disinfectants, hand sanitizer, and even hazmat suits. Preppers interviewed reported wearing protective gear and regular clothing that covered their entire bodies when outside of their homes. These precautions were also taken early on in the pandemic and without a government directive. For example, some urban preppers who traveled by plane for work began wearing face masks in January, months before the airline industry announced that face masks were recommended for travel in May. As LaChelle noted, "I couldn't believe that they told people that they didn't need to wear masks. You are trying to avoid catching a deadly virus. How could you not wear a mask? I stopped listening and did all that I could do to protect myself whenever I left home." Beyond wearing protective equipment, urban preppers also set up decontamination stations near their front doors to disinfect incoming packages (mail, newspapers and deliveries) and to remove clothing and footwear that had been worn outside.

While there are many references to pandemics in American popular culture, these urban preppers usually talked about only one reference, the film Contagion (2011). Contagion depicts the near-collapse of the world in the wake of a pandemic. A blockbuster in the year of its release and ranked number nineteen in the American "Disaster" film genre, (Box Office Mojo, 2019), Contagion has gained a renewed popularity due to the pandemic. This is likely due to its realistic and timely depiction of two important characteristics of life during the pandemic. First, Contagion reveals how a deadly virus can be spread so quickly through everyday contact. When comparing 
the film to his experience living in the pandemic, one urban prepper sighed and said, "It really is just like Contagion. COVID spreads so damn fast and so easily. You know, it's about trying to get your mind around it. Sure, you've got your stores and all you need. But, it's about the gradual, the ordinariness of it, the everyday bullshit, that's the real madness. Worrying about catching the virus just taking your trash down the hall to the compactor." Second, the film depicts the challenges of domestic life under quarantine. Another urban prepper, a mother of three children, shared her sadness about the changes to family life during the pandemic and likened it to the film: "Remember, in Contagion, when Matt Damon is struggling with letting his daughter go to the makeshift prom? My daughter is in her senior year of high school! What kind of senior year is this? She is supposed to be having fun, making memories like going to prom and going to the graduation ceremony. How am I supposed to find a substitute to make up for that? My heart's broken for her."

While learning sheltering in place strategies to ensure that one's family's needs are met during a pandemic are useful, these skills did not adequately prepare urban preppers for the many mental and physical challenges of everyday life during lockdown. As Julia explained, "I never really expected this. I always expected that, if something really bad happened in the city, we would have to bug out, that we'd be rushing somewhere and outside, trying to reach safety. I never thought that we would be stuck inside. . that the stress and the crazy would be about things like trying to schedule teaching and learning time for my three kids on a computer. Honestly, I thought that this was going to be about not having technology." Across the country, parents working from home struggled with remote learning problems ranging from learning different meeting platforms, trying to relearn and then teach something they had long forgotten to their children, or cajoling older children into submitting assignments (Harris, 2020). A Manhattan father of an elementary school student and prepper remarked about remote learning, "I was at work all the time. I was exhausted like everyone else. I alternated between taking meetings and teaching my son. As he worked his way through the lesson, I was on the iPad searching for enrichment materials to explain things to him. We were a tag-team. For next year, I'm going to try to find teacher manuals to help us through."

With New York City schools online by late April, children without access to a computer and a broadband connection were unable to engage in virtual learning. Before the pandemic, this limitation created a 'homework gap' that impacted students' ability to complement their schoolbased education with online resources at home, complete assignments, and access resources about college opportunities (U.S. Congress Joint Economic Committee, 2017). The pandemic exacerbated this "digital divide", as these students were completely denied access to online learning. Given the swift spread of the virus, New York's (DOE) quickly implemented a distance learning program with limited planning for its 1.1 million students, providing 475,000 devices including tablets and laptops to students (Gould, 2020). In addition to the challenges of online learning, the pandemic also impacted family life for New Yorkers by eliminating or greatly reducing the use of parks and public spaces. To prevent contracting COVID-19, parents were reluctant to use these spaces and then, once the city closed the playgrounds in April, unable to take 
their children to outside to play and enjoy a sense of freedom and fresh air. Few New Yorkers have the luxury of outdoor space, so park closures were particularly hard. Some urban preppers recognized that public space closures would be challenging for their children, so they prepared in advance. A Manhattan mother and prepper with two elementary school children created what she referred to as an "Activity Closet": "I made some space in my bedroom closet to store new games, books, and craft kits for the pandemic. When their spirits seemed low or I felt that we needed to change things up, I would sometimes bring out something new. Pick-up sticks was a great crowd pleaser. We also did fun workout routines that we found on YouTube. In our apartment, going stir crazy was contagious. Trust me, they had plenty of fights but we managed okay." Like so many New Yorkers, urban preppers have come to recognize that long-term sheltering in place requires not only a careful-work life balance for all members of the household, but dedicated time for enjoyment and discovery even in cramped quarters.

For urban preppers, the pandemic has been a lesson in endurance that has allowed them to test their mettle during a real-life disaster. Given their interest in protecting their families against disasters like pandemics, urban preppers were prepared to prevent the spread of the virus much earlier than other New Yorkers. All preppers reported being ready for the pandemic by the end of January, nearly two months before New York's shelter-in-place order on March 22. Prior to the pandemic, they already owned personal protective equipment and were familiar with the correct use of each item (such as wearing properly fitting N-95 masks). These urban preppers were able to refrain from panic buying to prepare for sheltering in place during the pandemic, because they had already stockpiled food and essential items in their prepper closets. All preppers indicated having at least a 30-day supply of provisions. Prior to and throughout the pandemic, these urban preppers also participated in information and resource exchange networks to prepare and assist others during the pandemic. Furthermore, many urban preppers served their respective communities by teaching neighbors how to prepare for the pandemic and helping to secure needed supplies (by donating supplies or providing a contact for the particular item).

While these urban preppers had a strong foundation for successfully preparing to shelter in place, they did not anticipate the unique challenges of staying in their homes for such an extended time period. Some preppers also believed that a great disaster would most likely involve leaving the city. Others also imagined that they would probably not have access to technology (the internet and laptops) during such crisis. Therefore, urban preppers came to recognize that long-term sheltering in place requires careful-work life balance for all members of the household. Remote learning was particularly taxing for employed parents as they juggled with helping their children to complete their schooling while simultaneously meeting their own job responsibilities. Furthermore, this strain was compounded when families competed for computer use and for broadband access.

Like most New Yorkers who sheltered in place for weeks, these urban preppers also struggled with the difficulties of living in a city devoid of its vibrancy and the opportunity to connect with others outside of one's home. Echoing the sentiments of other preppers, LaChelle said, "I've learned how difficult it is to live in a real-life lockdown, I really missed my family and 
my friends, especially my cousins. This has made me think about long-term community building. We are stronger together."

\section{Bugging Out}

While many city residents sheltered in place, New York's rich chose the second option for survival-leaving the city. Just as COVID hit, hundreds of thousands of New Yorkers, primarily from the wealthiest neighborhoods, fled the city. Between March and May, roughly 5\% of New York's population (about 420,000 residents) left the city based on an analysis of aggregated smartphone location data (Quealy, 2020). The residential population of the city's toniest neighborhoods like the Upper East Side, Soho, the West Village, and Brooklyn Heights dropped by $40 \%$ or more. Based on mail forwarding requests, many New Yorkers moved to nearby locations such as Long Island, New Jersey, and upstate New York (Paybarah et al., 2020). Wealthy New Yorkers often have second homes in these areas which include the Hamptons, the Jersey Shore, and the Hudson Valley. Following this first exodus by wealthy New Yorkers, the pandemic has also spurred the upper middle-class flight to the city's suburbs including New Jersey, Westchester County, Connecticut, and Long Island (Zaveri, 2020). A slow return to the city is expected; therefore, this decrease in the tax base is likely to affect economic recovery.

To prepare for a possible second wave of the virus in the Fall, these urban preppers plan to bolster their approaches to sheltering in place. Most urban preppers had placed orders for additional protective equipment by the spring to ensure delivery by September. Expecting that they will need to shelter in place for a prolonged period amidst a collapsing economy, some urban preppers are working to increase their prepper closet to contain provisions to last between six months to a year (this would require securing additional space such as a storage facility). Anticipating that school will be online, many urban preppers are also investing in new technology (buying additional laptops or tablets). To improve the ability of family members to access the internet simultaneously without difficulties, some preppers are boosting their modems to increase connection speeds. Urban preppers are even engaging in interior design by rearranging existing furniture or purchasing new furniture to provide designated work, learning, or entertainment spaces. Lastly, some preppers are working together to create a large survival cache (a large storage facility space that functions as a supply house) to support those needing assistance.

\section{Conclusion}

During the COVID-19 pandemic, urban preppers bolstered community resilience by relying on prepping strategies to protect themselves and shelter in place more effectively, and sharing their knowledge and resources with their neighbors. Their philosophy of self-reliance has helped them to survive the pandemic and brace for future surges. As noted by the Partnership for New York City (2020), "the pandemic unleashed political, racial and economic tensions that can either leave the nation's largest and most important urban center in chaos or. . provide the impetus for working together for recovery and positive change." Now, survival is dependent on the resilience of the city. 
The resilience of New York requires a clear, coordinated plan led by local government with the support of the business and nonprofit sectors as well as civic leaders. In other words, there needs to be a "bug out" plan to escape this chaos. At the time of writing, Mayor de Blasio is considering borrowing $\$ 7$ billion with the hope of federal aid, but without any significant budget cuts (New York Times Editorial Board, 2020). In response to fears about increasing homelessness and dirty streets affecting New York's economic recovery, 150 of the city's business leaders from organizations such as Goldman Sachs, JetBlue, Macy's, and Nasdaq, have sent an open letter to Mayor de Blasio urging the quick implementation of public safety and cleanliness initiatives to support businesses and employees in the return to work (Fitzsimmons \& Rubinstein, 2020). While the business leaders are viewed as only committed to financial policies, their appeal may act as an impetus for developing and advancing a city agenda. However, a plan for recovery must work toward decreasing social vulnerabilities, the social, cultural, and economic factors that shape a group's ability to respond to and recover from disaster (Masterson et al., 2014).

In a New York Times Op-Ed piece, Jerry Seinfeld identifies another critical element inherent in the city that may ensure its survival: its energy. Responding to those who argue that New York is now 'dead', Seinfeld argues that the energy found New York is what drives its resilience and its future. He refers to the energy found in cities; the spark ignites when city dwellers congregate together. Seinfeld (2020, para.12) writes that "Energy, attitude and personality cannot be 'remoted' through even the best optic lines" and that this special quality is what continues to draw people to New York. He is right. It is that city verve that Jane Jacobs (1961, p. 448) wrote about so long ago: "Dull, inert cities, it is true, do contain the seeds of their own destruction and little else. But lively, diverse, intense cities contain the seeds of their own regeneration, with energy enough to carry over for problems and needs outside themselves." 


\section{References}

Amandolare, S., Gallagher, L., Bowles, J., \& Dvorkin, E. (2020, June). Under threat \& left out: NYC's immigrants and the coronavirus crisis. Retrieved from https://nycfuture.org/research/under-threat-and-left-out

Barron, J. (2003, August 15). The blackout of 2003. The New York Times. Retrieved from https://www.nytimes.com/2003/08/15/nyregion/blackout-2003-overview-power-surgeblacks-northeast-hitting-cities-8-states.html.

Beauregard, R. A., \& Bounds, A. (2000). Urban citizenship. In E. F. Isin (Ed.), Democracy, citizenship and the global city (pp. 243-256). London: Routledge.

Beck, U. (2009). World at risk. Cambridge: Polity Press.

Biskind, P. (2018). The sky is falling: How vampires, zombies, androids, and superheroes made America great for extremism. New York: The New Press.

Bounds, A. (2020). Bracing for the apocalypse: an ethnographic study of New York's 'prepper' subculture. New York: Routledge.

Bowles, J., \& Moran, O. (2020). Recovery signs, new lows: NYC employment by industry since the outbreak of coronavirus. Retrieved from https://nycfuture.org/research/recoverysigns-new-lows

Box Office Mojo. (2019). Top gross earnings by genre. Retrieved from https://www.boxof cemojo.com/genres/chart/?id=disaster.html.

Cuomo, A. M. (2020, April 15). Amid ongoing COVID-19 pandemic, Governor Cuomo issues executive order requiring all people in New York to wear masks or face coverings in public. Retrieved from https://www.governor.ny.gov/news/amid-ongoing-Covid-19pandemic-governor-cuomo-issues-executive-order-requiring-all-people-new

Cuomo, A. M. (2020, March 20). Governor Cuomo signs the 'New York State on PAUSE' executive order. Retrieved from https://www.governor.ny.gov/news/governor-cuomosigns-new-york-state-pause-executive-order

Cuomo, A. M. (2020, March 24). Video, audio, photos \& rush transcript: Governor Cuomo: in New York, 'love wins and it will win again through this virus'. Retrieved from https://www.governor.ny.gov/news/video-audio-photos-rush-transcript-governor-cuomonew-york-love-wins-and-it-will-win-again

Deibert, M. (2019). When the sky fell: Hurricane Maria and the United States in Puerto Rico. New York: Apollo Publishers.

Department of Homeland Security. (2020, April 23). Food. Retrieved from https://www.ready.gov/food

Dolnick, S. (2011). Recovery is slower in New York suburbs. The New York Times. Retrieved from https://www.nytimes.com/2011/08/29/nyregion/wind-and-rain-from-hurricaneirene-lash-new-york.html

Dyson, M. E. (2006). Come hell or high water: Hurricane Katrina and the color of disaster. New York: Basic Civitas.

Faulkner, L., Brown, K., \& Quinn., T. (2018). Analyzing community resilience as an emergent property of dynamic social-ecological systems. Ecology and Society, 23(1), 24.

Fitzsimmons, E. G., \& Rubinstein, D. (2020, September 10). 150 big businesses warn mayor of 'widespread anxiety' over N.Y.C.'s future. Retrieved from https://www.nytimes.com/2020/09/10/nyregion/de-blasio-economy-coronavirus.html 
Foster, G. A. (2014). Hoarders, doomsday preppers, and the culture of apocalypse. New York: Palgrave Macmillan.

Geertz, C. (1973). Thick description: Toward an interpretive theory of culture. In Geertz, C. The interpretation of cultures: Selected essays. New York: Basic Books, (pp. 3-30).

Goodman, J. D. (2020, July 18). How delays and unheeded warnings hindered New York's virus fight. Retrieved from https://www.nytimes.com/2020/04/08/nyregion/new-yorkcoronavirus-response-delays.html

Gould, J. (2020, May 28). NYC Education Department can't say how many students are getting live instruction through remote learning. Retrieved from https://gothamist.com/news/nyceducation-department-cant-say-how-many-students-are-getting-live-instruction-throughremote-learning

Halle, D., \& Beveridge, A. A. (2013). New York and Los Angeles: The uncertain future. In D. Halle \& A. A. Beveridge (Eds.), New York and Los Angeles: The uncertain future. New York: Oxford University Press.

Harris, E. A. (2020, June 12). 'It was just too much': How remote learning is breaking parents. Retrieved from https://www.nytimes.com/2020/04/27/nyregion/coronavirushomeschooling-parents.html

Hartocollis, A. (2009, June 10). 12 flu victims have died, and ill may total 550,000. The New York Times. Retrieved from https://www.nytimes.com/2009/06/11/nyregion/11flu.html.

Huddleston, C. (2016). "Prepper" as resilient citizen: What preppers can teach us about surviving disasters. In M. Companion \& M. S. Chaiken (Eds.), Responses to disasters and climate change: Understanding vulnerability and fostering resilience (pp. 239-248). Boca Raton: CRC Press.

Jacobs, J. (1961). The death and life of great American cities. New York: Random House.

Kelly, C. R. (2016). The man-pocalpyse: Doomsday preppers and the rituals of apocalyptic manhood. Text and Performance Quarterly, 36, 95-114.

LaLone, M.B., (2012). Neighbors helping neighbors: An examination of the social capital mobilization process for community resilience to environmental disasters. Journal of Applied Social Science, 6(2), 209-237.

Lamy, P. (1996). Millennium rage: Survivalists, white supremacists, and the doomsday prophecy. New York: Plenum Press.

Lamy, P. (1997). Secularizing the millennium: Survivalists, militias, and the new world order. In T. Robbins \& S. J. Palmer (Eds.), Millennium, messiahs, and mayhem: Contemporary apocalyptic movements. New York: Routledge.

Lederer, K. (2020, March 18). New York's food distribution networks brace for an unprecedented threat. Retrieved from https://www.nytimes.com/2020/03/18/business/coronavirus-food-supply-kitchens.html

Lefebvre, H. (1991). The production of space. Oxford, UK: Blackwell Publishing.

Mayor's Office of Food Policy. (2019). Food Metrics Report 2019. Retrieved from https://www1.nyc.gov/assets/foodpolicy/downloads/pdf/Food-Policy-Report-2019.pdf

Masterson, J. H., Peacock, W. G., Zandt, S. S. V., Grover, H., Lori Feild Schwarz, \& John T. Cooper, J. (2014). Planning for community resilience: A handbook for reducing vulnerability to disasters. United States: Island Press

Mays, J. C., \& Newman, A. (2020, June 26). Virus is twice as deadly for black and latino people than whites in N.Y.C. Retrieved from https://www.nytimes.com/2020/04/08/nyregion/coronavirus-race-deaths.html 
McGeehan, P. (2020, July 23). A million jobs lost: a 'heart attack' for the N.Y.C. economy. Retrieved from https:/www.nytimes.com/2020/07/07/nyregion/nyc-unemployment.html

McKinley, J. C. M., \& Santora, M. (2016, February 11). 5 arrested in connection with East Village gas explosion. The New York Times. Retrieved from https://www.nytimes.com/2016/02/12/nyregion/5-arrested-in-connection-with-eastvillage-gas-explosion.html.

McManus, D. (2020, April 8). Column: Trump's 'I'm not responsible' presidency. Retrieved from https://www.latimes.com/politics/story/2020-04-08/trumps-im-not-responsiblepresidency

Mills, M. F. (2018). Preparing for the unknown... unknowns: 'Doomsday' prepping and disaster risk anxiety in the United States. Journal of Risk Research, 1-13.

Mitchell, R. G. (2002). Dancing at armageddon: Survivalism and chaos in modern times. Chicago: University of Chicago Press.

National Bureau of Economic Research. (2010, September 20). Business cycle dating committee report. Retrieved from https://www.nber.org/cycles/sept2010.html.

New York City Department of Health. (2019). Zika virus. Retrieved from https://www1.nyc.gov/site/doh/health/health-topics/zika-virus.page.

New York City Health Department. (2020, May 18). Main data page. Retrieved from https://www1.nyc.gov/site/doh/covid/covid-19-data.page

New York City Special Initiative for Rebuilding and Resiliency. (2013). Plan NYC: A stronger, more resilient New York. Retrieved from http://smedia.nyc.gov/agencies/sirr/SIRR_singles_Lo_res.pdf.

New York State Department of Labor. (2020, March 31). Labor force and unemployment data. Retrieved from https://www.labor.ny.gov/stats/LSLAUS.shtm

Partnership for New York City. (2020, July). A call for action and collaboration. Retrieved from https://pfnyc.org/wp-content/uploads/2020/07/actionandcollaboration.pdf

Partnership for New York City. (2020, June). New York City COVID-19 economic impact update. Retrieved from https://pfnyc.org/research/new-york-city-covid-19-economicimpact-update/

Paybarah, A., Bloch, M., \& Reinhard, S. (2020, May 16). Where New Yorkers moved to escape Coronavirus. Retrieved from https://www.nytimes.com/interactive/2020/05/16/nyregion/nyc-coronavirus-movingleaving.html

Perry, R. W. (2006). What is a disaster? In E. L. Quarantelli, H. Rodriguez, \& R. R. Dynes (Eds.), Handbook of disaster research (pp. 1-15). New York: Springer.

Perry, R. W. (2018). Defining disaster. In H. D. Rodríguez, W. Donner, \& J.E. Trainor, (Eds.), Handbook of disaster research (2nd ed., pp. 3-22). Cham, Switzerland: Springer.

Plodinec, M. J. 2009. (2011, February 19). Definitions of resilience: An analysis. community \& regional resilience institute (CARRI). Retrieved from http://www.resilientus.org/library/CARRI_Definitions_Dec_2009_1262802355.pdf

Protesters against Wall Street. (2011, October 8). The New York Times. Retrieved from https://www.nytimes.com/2011/10/09/opinion/sunday/protesters-against-wallstreet.html 
Quarantelli, E. L. (2000). Disaster research. In E. F. Borgatta \& R. J. V. Montgomery (Eds.), Encyclopedia of sociology (pp. 682-688). New York, NY: Macmillan.

Quealy, K. (2020, May 15). The richest neighborhoods emptied out most as Coronavirus hit New York City. Retrieved from https://www.nytimes.com/interactive/2020/05/15/upshot/wholeft-new-york-coronavirus.html

Rajan, R. G. (2011). Fault lines: How hidden fractures still threaten the world economy. Princeton: Princeton University Press.

Reinhardt, G. Y. (2017). Imagining worse than reality: Comparing beliefs and intentions between disaster evacuees and survey respondents. Journal of Risk Research, 20(2), 169194.

Rivera, R., \& Roston, M. (2010, September 16). New York City battered by fierce storm. The New York Times. Retrieved from https://www.nytimes.com/2010/09/17/nyregion/17storm.html.

Santora, M. (2014). First patient quarantined under strict new policy tests negative for ebola. The New York Times. Retrieved from https://www.nytimes.com/2014/10/25/nyregion/newyork-ebola-case-craig-spencer.html? searchResultPosition=3.

Santora, M., \& Maag, C. (2012, September 8). Tornadoes touch down in Brooklyn and Queens. The New York Times. Retrieved from https://www.nytimes.com/2012/09/09/nyregion/tornado-causes-damage-along-a-beachin-queens.html.

Schwirtz, M., \& Cook, L. R. (2020). These N.Y.C. neighborhoods have the highest rates of virus deaths. The New York Times. Retrieved from https://www.nytimes.com/2020/05/18/nyregion/coronavirus-deaths-nyc.html

Seinfeld, J. (2020, August 24). https://www.nytimes.com/2020/08/24/opinion/jerry-seinfeldnew-york-coronavirus.html.

Shamberg, M. Sher, S. and Jacobs, G. (Producers), Soderbergh, S. (Director). (2011). Contagion. United States: Participant Media, Image Nation Abu Dhabi.

Shear, M. D., Weiland, N., Lipton, E., Haberman, M., \& Sanger, D. E. (2020, July 28). Inside Trump's failure: The rush to abandon leadership role on the virus. Retrieved from https://www.nytimes.com/2020/07/18/us/politics/trump-coronavirus-response-failureleadership.html

Sorkin, A. R. (2009). Too big to fail: The inside story of how Wall Street and Washington fought to save the financial system-and themselves. New York: Viking.

The Editorial Board. (2020, June 7). Mayor de Blasio, don't make New York's budget crisis worse. Retrieved from https://www.nytimes.com/2020/06/07/opinion/new-york-citybudget.html

U.S. Congress Joint Economic Committee. (2017, September). America's digital divide. Retrieved from https://www.jec.senate.gov/public/_cache/files/ff7b3d0b-bc00-44989f9d-3e56ef95088f/the-digital-divide-.pdf

Viladrich, A. (2020, July 16). COVID-19 amplified: Deconstructing immigrants' vulnerability during pandemic times. Retrieved from http://www.roosevelthouse.hunter.cuny.edu/?forum-post=covid-19-amplifieddeconstructing-immigrants-vulnerability-pandemic-times

Webb, G. R. (2018). The cultural turn in disaster research: Understanding resilience and vulnerability through the lens of culture. In H. Rodríguez, W. Donner, \& J. E. 
Trainor (Eds.), Handbook of disaster research (pp. 109-121). Cham, Switzerland: Springer.

Zaveri, M. (2020, August 31). Suburban home sales boom as people move out of N.Y.C. Retrieved from https://www.nytimes.com/2020/08/31/nyregion/suburbs-nycpandemic.html 